\title{
STRATEGI INTEGRASI DAN DESAIN PERANGKAT PEMBELAJARAN SAINS TERPADU BERBASIS ICT UNTUK PEMBELAJARAN SISWA SMP KELAS VIII
}

\author{
Asrizal, Jurusan Fisika FMIPA Universitas Negeri Padang \\ asrizal_unp@yahoo.com
}

\begin{abstract}
Integration is an interesting idea in curriculum 2013. Integration of a branch of Science and an other branch of Science, character values, and ICT skills in learning process are very important in curriculum 2013 for senior high school. Science shows itself in a unity. Fact shows that Science in Senior High School is still separated. First objective of this discussion is to explain the method to integrate the other branch of science, character values, and ICT skills into learning material. Second objective is to describe the initial product of learning set base on ICT. There are two results of this discussion. First, Integration between a branch science and other branch science can be conducted by implementing a type of integrated science such separated, connected, shared, integrated, etc; integration the character values into learning material conducted by information, instruction, or analogy; and integration ICT skills into learning material conducted by navigation system. Second, as product of integrated science learning set base on ICT consist of learning material, student worksheet, assessment instrument.
\end{abstract}

Keywords: Strategy, Science, Integrated Science, Character Values, ICT, Student

\section{PENDAHULUAN}

Kemajuan Sains dan Teknologi telah memberikan manfaat dan perubahan dalam kehidupan manusia. Manusia telah merasakan manfaat dari hasil-hasil Sains dan Teknologi dalam kehidupannya baik dalam bentuk sederhana maupun dalam bentuk yang lebih canggih. Pemanfaatan hasil-hasil Sains dan Teknologi dalam kehidupan telah membawa perubahan perilaku manusia seperti dalam berkomuni kasi dan bergaul.

Kehidupan dalam masyarakat telah berkembang seiring dengan perkembang an Sains dan Teknologi. Kemajuan Sains dan teknologi menuntut manusia semakin bekerja keras untuk menyesuaikan diri dalam berbagai aspek kehidupan. Eksis tensi dalam aspek pendidikan akan menentukan keberhasilan kehidupan manu sia yang penuh tantangan dan persaingan. Proses pendidikan seharusnya mampu membentuk manusia yang melek terhadap Sains dan Teknologi secara utuh.

Pendidikan Sains memiliki peran penting dalam menyiapkan siswa untuk memasuki dunia kehidupannya. Dengan dasar ini, pendidikan Sains memiliki potensi besar dan peranan strategis dalam menyiapkan SDM berkualitas untuk menghadapi era globalisasi. Potensi baik ini dapat diwujudkan jika pendidikan Sains mampu melahirkan siswa yang terampil dalam bidangnya dan mampu menumbuhkan keterampilan berpikir seca ra logis, keterampilan berpikir kreatif, keterampilan memecahkan masalah, mene rapkan sikap kritis, menguasai teknologi, dan mampu beradaptasi terhadap perubah an dan perkembangan zaman. 
Kurikulum 2013 mendorong adanya integrasi dalam suatu mata pelajaran. Integrasi pertama adanya keterkaitan antara suatu bidang ilmu dengan bidang ilmu lainnya dalam Sains. Dalam kehidupan nyata Sains memperlihatkan dirinya dalam satu kesatuan. Dengan dasar ini seharusnya pembelajaran Sains dilaku kan secara terpadu, baik gejala alam maupun materi yang terkandung di alam semesta merupakan satu kesatuan. Sains merupakan suatu ilmu yang mempelajari tentang gejala alam, materi, dan interaksi diantaranya. Alam dalam kehidupan nyata memperlihatkan dirinya kepada manusia sebagai satu kesatuan. Sebagai contoh udara merupakan bagian alam yang tidak hanya dapat dilihat dari aspek Fisika, Kimia, atau Biologi, tetapi merupakan kesatuan udara dengan segala kandungan dan sifat-sifatntya (Das S : 2009).

Pembelajaran terpadu merupakan suatu pendekatan pembelajaran yang secara sengaja menghubungkan antara beberapa aspek baik hubungan dalam mata pelajaran sendiri maupun antara mata pelajaran. Dengan keterpaduan siswa memperoleh pengetahuan dan keterampil an secara utuh sehingga pembelajaran menjadi bermakna. Pembelajaran bermak na berarti siswa dapat memahami konsep Sains yang dipelajari melalui pengalaman secara langsung dengan menghubungkan antara konsep dalam suatu mata pelajaran maupun antara mata pelajaran (Rudi U: 2011). Pembelajaran Sains terpadu mendo rong siswa memiliki wawasan yang lebih luas karena mereka mengenal adanya hubungan antara bidang ilmu dalam Sains.

Dari segi ilmu psikologi dan pendi dikan diketahui bahwa seorang siswa akan lebih mudah mengenal dan memahami benda-benda di alam secara keseluruhan terlebih dahulu dibandingkan dengan memahami bagian-bagiannya yang lebih kecil (Das S: 2009). Dengan alasan ini, pembelajaran Sains terpadu sesuai diterap kan untuk siswa SMP dibandingkan jika diberikan secara terpisah. Pembelajaran Sains terpadu dipercaya mampu menum buhkan kreativitas dan membuat siswa senang dalam pembelajaran sehingga sesuai dengan tuntutan standar proses.

Sesuai dengan standar proses seharusnya pembelajaran Sains dapat dilakukan secara interaktif, inspiratif, menyenangkan, menantang, memotivasi siswa untuk berpartisipasi secara aktif, dan memberikan ruang yang cukup untuk mengembangkan prakarsa, kreativitas, dan kemandirian siswa. Dengan cara ini siswa dapat mengkonstruksi pengetahuan sains melalui proses Sains. Melalui proses Sains dapat mengembangkan sikap ilmiah seperti jujur, terbuka, objektif, dan sebagainya.

Model pembelajaran Sains terpadu direkomendasikan untuk tingkat SMP, karena ternyata memiliki beberapa tujuan yaitu: meningkatkan efesiensi dan efekti vitas pembelajaran, meningkatkan minat dan motivasi, dan mencapai kompetensi dasar sekaligus. Keunggulan pembelajaran Sains terpadu: efisien dan efektif, materimateri tidak saling tumpang tindih antara satu dengan yang lain. Keunggulan lain dari pembelajaran Sains terpadu adalah menghemat waktu pembelajaran untuk kegiatan lapangan, meningkatkan minat dan motivasi, mempermudah dan memoti vasi siswa untuk memahami konsep penge tahuan secara menyeluruh. Dengan model pembelajaran Sains terpadu beberapa kom petensi dasar dapat dicapai sekaligus, menghemat waktu, tenaga dan sarana, dan biaya pendidikan (Ari G: 2011).

Melalui pembelajaran Sains terpadu, siswa dapat memperoleh pengalaman secara langsung. Dengan cara ini mereka dapat menambah kekuatan untuk meneri ma, menyimpan, dan menerapkan konsep yang telah dipelajarinya. Pembelajaran terpadu melatih siswa untuk menemukan sendiri berbagai konsep yang dipelajari secara menyeluruh, bermakna, autentik dan aktif. Pencapaian keutuhan belajar 
Sains, kebulatan pandangan tentang kehidupan, dunia nyata, dan fenomena alam hanya dapat direfleksikan melalui pembelajaran terpadu (Suheri S: 2011).

Hasil penelitian menunjukkan bah wa pembelajaran Sains terpadu dapat memudahkan dan memotivasi siswa untuk mengenal, menerima, menyerap, dan memahami hubungan antara konsep pengetahuan dan nilai yang termuat dalam tema tersebut. Siswa terbiasa berpikir ter arah, teratur, utuh, menyeluruh, sistemik, dan analitik. Siswa juga termotivasi dalam belajar bila mereka merasa bahwa pem belajaran itu bermakna baginya. Penerap an Sains terpadu mempengaruhi literasi Sains siswa (Yeni H: 2010).

Integrasi kedua yang perlu dilaku kan dalam pembelajaran adalah nilai karakter. Pembentukan nilai karakter siswa penting dilakukan dalam proses pembelajaran. Pengintegrasian nilai-nilai karakter bangsa kedalam kegiatan pem belajaran berarti memadukan, memasuk kan, dan menerapkan nilai-nilai yang diyakini baik dan benar dalam rangka membentuk, mengembangkan, dan mem bina tabiat atau kepribadian peserta didik sesuai jatidiri bangsa tatkala kegiatan pembelajaran berlangsung. Integrasi nilainilai karakter bangsa pada kegiatan pembelajaran dapat dilakukan melalui tahap-tahap: perencanaan, pelaksanaan, dan evaluasi (Anik G: 2009).

Pembentukan karakter merupakan proses yang berlangsung seumur hidup. Untuk membentuk karakter siswa, perlu diperhatikan tiga hal yang berlangsung secara terintegrasi. Pertama, pembelajaran membuat siswa mengerti baik dan buruk, mengerti tindakan yang perlu dilakukan, dan menentukan perioritas hal-hal yang baik. Kedua, siswa mempunyai kecintaan terhadap kebaikan dan menghindari per buatan yang buruk. Ketiga, siswa mampu melakukan kebajikan dalam hidupnya dan membiasakan penerapannya dalam kehi dupan sehari-hari.
Implementasi pendidikan karakter merupakan suatu alternatif untuk menum buhkan dan mengembangkan karakter siswa dalam pembelajaran. Integrasi nilai karakter dalam pembelajaran akan menum buhkan nilai karakter siswa secara berkelanjutan. Ada beberapa nilai karakter dasar yang perlu ditumbuhkan. Menurut ahli psikolog nilai karakter dasar manusia adalah: cinta kepada Allah dan ciptaanNya, tanggung jawab, jujur, hormat dan santun, kasih sayang, peduli, kerja sama, percaya diri, kreatif, kerja keras, dan pantang menyerah, keadilan dan kepemim pinan, baik dan rendah hati, toleransi, cinta damai, dan cinta persatuan (Akhmad S: 2010).

Dalam pendidikan di Indonesia ada 18 nilai karakter dikembangkan menurut kemendiknas. Delapan belas nilai yang perlu diintegrasikan dalam pendidikan yaitu: religius, jujur, toleransi, disiplin, kerja keras, kreatif, mandiri, demokratis, rasa ingin tahu, semangat kebangsaan, cinta tanah air, menghargai prestasi, bersa habat/komunikatif, cinta damai, gemar membaca, peduli lingkungan, peduli sosial dan tanggung tawab (Umi R: 2011).

Pembentukan karakter yang baik memberikan pengaruh yang berarti terhadap keberhasilan seseorang. Berdasar kan penelitian di Harvard University Amerika Serikat dalam Akhmad S (2010), "kenyataan menunjukkan bahwa kesukses an seseorang tidak ditentukan sematamata oleh keterampilan keras saja tetapi lebih ditentukan oleh keterampilan lunak. Penelitian ini mengungkapkan, kesukses an hanya ditentukan sekitar 20 persen oleh keterampilan keras dan sisanya 80 persen oleh keterampilan lunak". Penelitian ini mengungkapkan, kesuksesan hanya diten tukan sekitar 20 persen oleh keterampilan keras dan sisanya 80 persen oleh keterampilan lunak". Orang-orang sukses di dunia bisa berhasil karena lebih banyak didukung keterampilan lunak daripada keterampilan keras. 
Integrasi ketiga yang perlu dilaku kan dalam pembelajaran adalah keteram pilan menerapkan informasi dan tekno logi. Teknologi informasi dan komunikasi merupakan ilmu yang mempelajari ten tang desain, pengembangan, implement tasi, manejemen sistem informasi berbasis komputer khususnya aplikasi software dan hardware. ICT berhubungan dengan peng gunaan komputer secara elektronik dan software komputer untuk mengubah, menyimpan, memproteksi, memproses, mentransmisikan, dan memanggil kembali segala informasi secara aman (Muham $\operatorname{mad} \mathrm{Y}: 2010)$.

Teknologi informasi memberi pene kanan pada pelaksanaan dan pengolahan data seperti menangkap, mentransmisikan, menyimpan, mengambil, memanipulasi atau menampilkan data dengan mengguna kan perangkat teknologi elektronik terutama komputer. Disisi lain teknologi komunikasi menekankan pada pengguna an perangkat teknologi elektronika pada aspek ketercapaiaan tujuan dalam proses komunikasi. Dengan teknologi dan komu nikasi data dan informasi yang diolah dapat memenuhi kriteria komunikasi yang efektif (Ceppy R : 2009).

ICT telah diterapkan dalam proses pembelajaran. Secara umum ada tiga fungsi utama ICT dalam kegiatan pembe lajaran. Pertama, teknologi berfungsi sebagai alat dalam pembelajaran. ICT dapat digunakan sebagai alat bagi siswa untuk membantu proses pembelajaran. Kedua, teknologi berfungsi sebagai ilmu pengetahuan. Teknologi dapat dipandang sebagai bagian dari disiplin ilmu yang harus dikuasai oleh siswa. Ketiga, tekno logi berfungsi sebagai bahan dan alat bantu untuk pembelajaran. Teknologi dapat dimaknai sebagai bahan pembelajar an dan sebagai alat bantu untuk menguasai sebuah kompetensi berbantuan komputer (Ceppy R :2008).

Pemanfaatan ICT bagi guru adalah kunci utama dalam meningkatkan kualitas pendidikan. Dalam konteks ini ICT dapat dimanfaatkan sebagai media pembelajar an, pengembangan profesional guru, dan pengembangan sistem pengelolaan belajar dan sumber belajar. Kekuatan perubahan dalam kurikulum, yang meliputi perubah an tujuan dan isi, aktivitas belajar, latihan dan penilaian, hasil akhir belajar, serta nilai tambah yang positif. Kekuatan ICT telah mendorong terjadinya perubahan dalam pembelajaran. Pemanfaatan ICT pada pembelajaran memberikan banyak keuntungan, baik bagi siswa, guru, maupun pengelola pendidikan. ICT dapat memfasilitasi model pembelajaran yang berpusat pada siswa, sehingga mereka dapat lebih aktif dan kreatif (Budi M: 2007). ICT telah mendorong terjadinya

Berdasarkan hasil pengamatan penulis pada kegiatan bimbingan teknis dan supervisi kelas di Sumatera Barat ternyata pelaksanaan pembelajaran Sains di SMP dilakukan secara terpisah-pisah. Pada umumnya kompetensi yang berhubungan dengan materi Biologi diajarkan oleh guru Biologi, kompetensi yang berhubungan dengan materi Fisika diajarkan oleh guru Fisika. Disisi lain kompetensi yang berhubungan dengan materi Kimia diajarkan oleh guru Fisika atau guru Biologi. Dengan cara seperti ini mata pelajaran IPA di SMP sering dikenal dengan IPA Fisika, IPA Biologi, dan IPA Kimia.

Dengan penerapan pembelajaran Sains secara terpisah-pisah menyebabkan penguasaan siswa terhadap Sains menjadi rendah. Fakta ini diperkuat oleh hasil studi PISA tahun 2006 menyatakan bahwa kemampuan literasi Sains siswa Indonesia berada pada kategori rendah. Indonesia berada pada peringkat ke 50 dari 57 negara. Data menunjukkan bahwa skor rata-rata Sains siswa Indonesia adalah 393. Hasil studi PISA memperlihatkan bahwa masing-masing tingkat literasi jauh di bawah kemampuan rata-rata negaranegara yang disurvey (Elsy Z : 2013). 
Untuk lebih memfokuskan pemba hasan ini perlu dilakukan pembatasan masalah. Pertama, strategi berhubungan dengan kiat-kiat tertentu yang dapat dilakukan untuk mengintegrasikan suatu bidang Sains dengan bidang Sains lainnya dalam suatu mata pelajaran, nilai karakter, dan keterampilan ICT ke dalam perangkat pembelajaran. Kedua, Sains terpadu untuk siswa SMP meliputi tiga bidang ilmu yaitu Biologi, Fisika, dan Kimia.

Tujuan dari penulisan artikel ini adalah untuk menjelaskan altenatif cara mengintegrasikan bidang ilmu dalam Sains, nilai karakter, dan keterampilan ICT dalam perangkat pembelajaran. Ketiga, menggambarkan karakteristik produk perangkat pembelajaran Sains terpadu mengintegrasikan nilai karakter untuk pembelajaran siswa SMP.

\section{PEMBAHASAN}

Pengintegrasian suatu bidang ilmu dengan bidang ilmu lain lain sains, nilai karakter, dan keterampilan ICT penting dalam dalam pembelajaran. Secara umum ada dua hasil pembahasan dalam tulisan ini. Pertama, cara integrasi antara bidang dalam Sains, integrasi nilai karakter, dan integrasi keterampilan ICT. Kedua, desain utama dari produk perangkat pembelajar an berbasis ICT dengan mengintegrasikan nilai karakter.

\section{Cara Integrasi Dalam Perangkat Pembelajaran}

a. Integrasi Antar Bidang Ilmu Sains

Pada dasarnya suatu ilmu dalam bidang Sains tidak terpisah antara satu dengan yang lainnya. Dengan dasar ini penginteg rasian antara bidang ilmu dalam Sains perlu dilakukan. Pengintegrasian antara bidang ilmu Sains ini sering dikenal Sains terpadu.

Banyak altenarnatif yang dapat dilakukan untuk mengintegrasikan bidang ilmu Sains. Sebagai contoh pengintegrasi an Sains adalah menerapkan salah satu dari model pembelajaran terpadu seperti tipe keterkaitan (connected), terpisah (fragmented), terkumpul (nested), terurut (sequenced), terbagi (shared), terintegrasi (integrated), dan sebagainya. Pemilihan model pembelajaran terpadu sangat tergantung kepada keterkaitan antara satu kompetensi dengan kompetensi lainnya dalam bidang Sains. Salah satu alternatif yang lebih mudah menerapkan Sains terpadu adalah tipe keterkaitan.

Pembelajaran terpadu model keter kaitan adalah salah satu model pembelajar an terpadu yang menghubungkan satu konsep dengan konsep lain, satu topik dengan topik lain, satu keterampilan dengan keterampilan lainnya, satu tugas dengan tugas lainnya, dan satu ide dengan ide lainnya dalam satu bidang studi (Novi R: 2012). Dengan cara seperti ini, satu bidang Sains dalam suatu mata pelajaran saling terkait antara satu bidang dengan bidang yang lainnya. Model pembelajaran ini menyajikan hubungan yang nyata di dalam suatu mata pelajaran dengan cara menghubungkan satu topik dengan topik yang lain, satu konsep ke konsep yang lain, satu keterampilan dengan keterampil an yang lain, atau satu tugas ke tugas yang lain (Nur F: 2010).

Model pembelajaran Sains terpadu tipe keterkaitan menghubungkan suatu topik bidang ilmu Sains dengan bidang ilmu Sains lainnya. Karakteristik dari model keterkaitan antara lain: adanya hubungan satu konsep dengan konsep lain, satu topik dengan topik lain, satu keterampilan dengan keterampilan lain, atau satu ide dengan ide yang lain tetapi masih dalam lingkup suatu bidang studi. Sebagai contoh keterpaduan adalah bagian ilmu dalam mata pelajaran IPA di SMP.

Dalam model ini keterkaitan dapat dalam bentuk topik, konsep, atau keteram pilan dalam Sains. Keterkaitan ini perlu dinyatakan secara nyata baik dalam materi maupun dalam pembelajaran. Keuntungan 
dari tipe keterkaitan adalah konsep-konsep utama dalam Sains saling terhubung, mengarah pada pengulangan, konsep tualisasi ulang, dan mengasimilasi gagas an dalam satu disiplin. Disisi lain kelemah an dari tipe keterkaitan adalah disiplin bidang ilmu Sains tidak berkaitan dan materi pelajaran tetap fokus pada satu disiplin bidang Sains.

\section{b. Integrasi Nilai Karakter}

Pembentukan dan pengembangan nilai karakter dalam pembelajaran perlu dilakukan secara berkelan jutan dalam proses pembelajaran. Menurut kurikulum 2013 pembelajaran yang dilaksanakan pada kegiatan inti dilakukan untuk membentuk kompetensi siswa. Kompeten si meliputi pengetahuan, sikap, dan keterampilan. Dalam prakteknya, pemben tukan pengetahuan dan keterampil an dilakukan terlebih dahulu. Efek penyerta dari pembentukan pengetahuan dan keterampilan adalah terbentuknya karakter siswa selama kegiatan inti.

Pengintegrasian nilai pendidikan karakter dapat pula dilakukan melalui perangkat pembelajaran. Dalam kuriku lum 2013, nilai-nilai karakter pada suatu mata pelajaran telah diintegrasikan pada kompetensi spiritual dan kompetensi sosial pada kompetensi inti. Dari kedua kompetensi inti ini, nilai karakter diturunkan ke kompetensi dasar. Karena itu, dalam kurikulum 2013 nilai karakter lebih mudah diintegrasikan ke dalam silabus dan RPP.

Integrasi nilai karakter dalam bahan ajar dapat dilakukan melalui beberapa cara. Pertama, melalui instruksi pada beberapa bagian bahan ajar seperti panduan dan latihan. Kedua, melalui informasi dalam materi pembelajaran. Ketiga, melalui analogi dari suatu konsep atau prinsip dari Sains dalam bahan ajar.

Strategi integrasi nilai karakter melalui instruksi dalam bahan ajar lebih mudah dilakukan. Dengan memberikan perintah, nasehat, larangan pada bagian tertentu nilai karakter dapat ditumbuhlan. Sebagai contoh instruksi dalam latihan yang dapat diberikan antara lain: bacalah doa sebelum mengerjakan latihan agar hati menjadi tenteram, kerjakanlah latihan dengan sunguh-sunguh agar didapat hasil yang lebih optimal, bekerjalah dalam kelompok dengan saling bersahabat, menghargai, dan komunikatif. Kerjakan lah latihan dalam bahan ajar dalam waktu 30 menit dengan bertanggung jawab.

Strategi integrasi nilai karakter kedua dalam bahan ajar yang dapat dilaku kan adalah melalui materi pembelajaranr. Informasi nilai karakter dapat dihubung kan dengan nilai religius, rasa ingin tahu, dan gemar membaca. Sebagai contoh materi energi dapat dihubungkan dengan kebesaran dan kekuasaan kebesaran Tuhan dalam menciptakan matahari seba gai sumber energi utama dalam kehidupan dimuka bumi. Siswa diharapkan memikirk an, memanfaatkan, dan menyukuri tentang hasil ciptaan Tuhan ini.

Strategi integrasi nilai karakter dalam bahan ajar yang ketiga adalah melalui analogi dengan mengambil makna yang tersirat dalam suatu konsep, prinsip, atau hukum dalam Sains. Pada hakikatnya Sain merupakan suatu ilmu pengetahuan yang mempelajari tentang hasil ciptaan Tuhan. Dari segi Sains, secara umum hasil ciptaan Tuhan ada dua bagian yaitu peristiwa dan benda di alam semesta.

Banyak makna dan pelajaran yang dapat diambil dari mempelajari peristiwa alam dan benda-benda. Sebagai contoh matahari setiap hari memancarkan energinya ke permukaan bumi dalam bentuk radiasi. Energi matahari digunakan oleh tumbuh-tumbuhan untuk proses fotosintesis. Disisi lain zat-zat makanan di sekitar akar tanaman dibawa oleh air ke daun. Pada daun terjadi perubahan energi cahaya kedalam energi kimia. Makna yang dapat diambil adalah saling adanya interaksi dan kerjasama dalam proses fotosistensis pada tanaman. 
c. Integrasi Keterampilan ICT

Pada dasarnya keterampilan ICT dapat dintegrasikan pada semua mata pelajaran. Keterampilan ICT merupakan proses mengolah dan menyimpan infor masi menggunakan peralatan komputer. Informasi dalam ICT mencakup kom ponen-komponen multimedia seperti teks, suara, gambar, animasi, dan video.

Integrasi keterampilan ICT dalam bahan ajar Sains terpadu dapat dilakukan melalui beberapa cara. Pertama, keteram pilan siswa mengakses sumber belajar yang ada dalam bahan ajar melalui menu dan hyperlink. Kedua, keterampilan siswa berkomunikasi dengan guru melalui forum dan chatting. Ketiga, keterampilan siswa dalam mengerjakan latihan secara online. Keempat, keterampilan mengerjakan evaluasi interaktif dalam bahan ajar sehingga mereka dapat menilai diri sendiri. Kelima keterampilan mengakses sumber belajar di internet melalui tugas yang diberikan dalam suatu tugas. Dengan cara pembelajaran seperti ini, keterampil an ICT siswa dapat dikembangkan.

\section{Produk Hasil Integrasi}

Produk hasil integrasi antara bidang ilmu dalam Sains, integrasi nilai karakter, dan integrasi keterampilan ICT dibuat menggunakan software moodle. Halaman utama dari perangkat pembelajaran berba sis ICT diperlihatkan pada Gambar 1

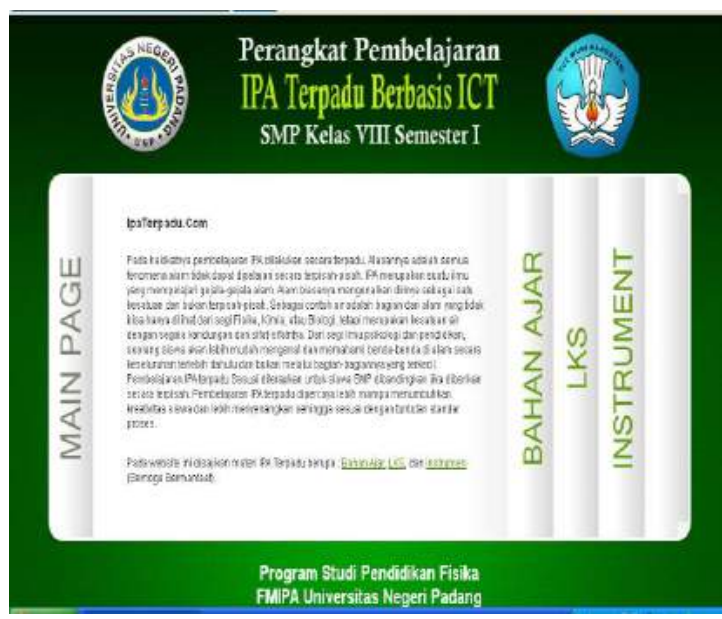

Gambar 1. Halaman Utama Produk
Alamat dari produk perangkat pembelajaran berbasis ICT adalah ipaterpadu.com. Pada halaman utama produk digambarkan tentang Sains terpadu, alasan Sains terpadu bagi siswa SMP, dan manfaat Sains terpadu bagi siswa SMP. Sains terpadu mengintegrasi kan nilai karakter berbasis ICT secara umum terdiri dari tiga bagian yaitu: bahan ajar ICT, lembar kerja siswa, dan instrumen evaluasi pembelajaran. Penggu na diberi pilihan untuk menggunakan salah satu diantara ketiga perangkat pembelajaran yang disediakan.

Pilihan pertama dari perangkat pembelajaran berbasis ICT adalah bahan ajar. Pengguna diberi gambaran tentang bahan ajar berbasis ICT seperti diperlihat kan pada Gambar 2

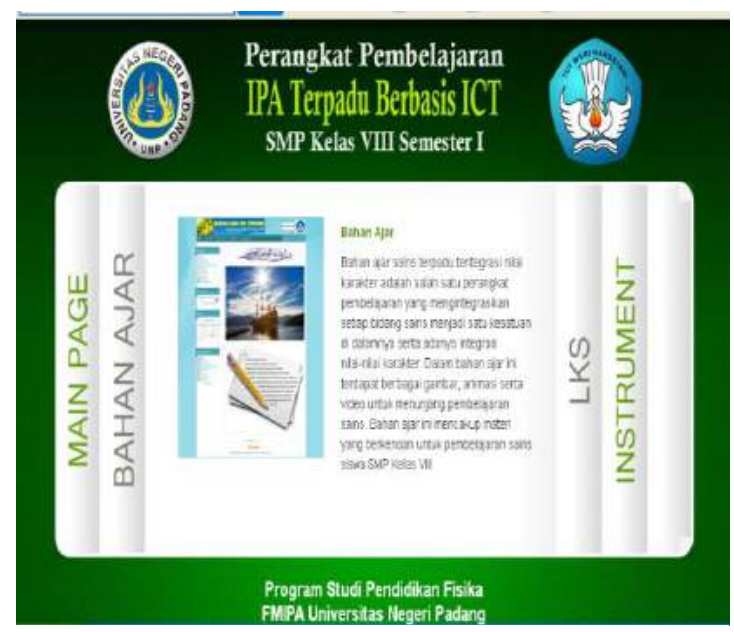

Gambar 2. Halaman Utama Bahan Ajar

Pada halaman bahan ajar pengguna diberi gambaran tentang bahan ajar berbasis Sains terpadu berbasis ICT dengan mengintegrasikan nilai karakter. Bahan ajar berbasis ICT adalah suatu bahan ajar yang dikembangkan dengan mengintegrasikan antara bidang Sains menggunakan tipe keterkaitan dan mengintegrasikan nilai karakter. Pengguna dapat masuk ke bahan ajar dengan cara mengklik bahan ajar pada judul.

Pilihan kedua dalam perangkat pembelajaran berbasis ICT adalah LKS 
Sains terpadu berbasis ICT dengan mengintegrasikan nilai karakter. Tampilan halaman utama dari LKS dapat diperhatikan pada Gambar 3

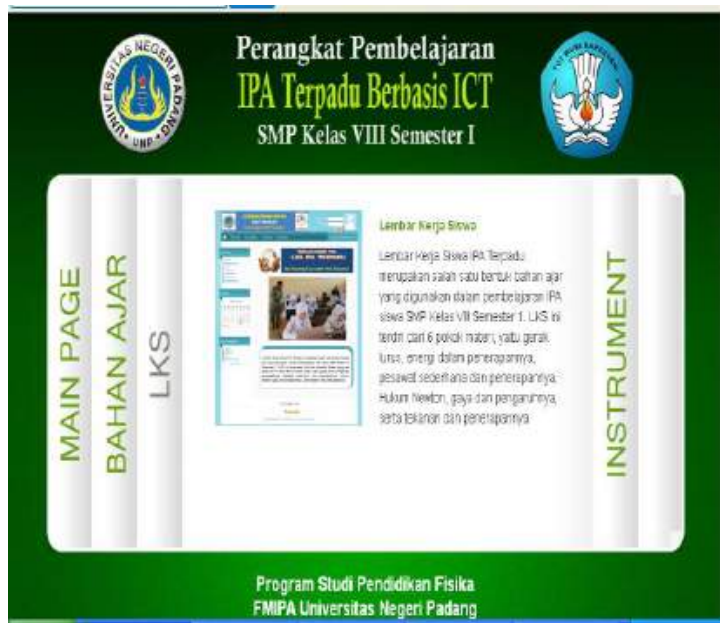

Gambar 3. Halaman Utama LKS

Pilihan ketiga pengguna dalam perangkat pembelajaran berbasis ICT adalah evaluasi pembelajaran. Tampilan halaman utama evaluasi pembelajaran dapat diperhatikan pada Gambar 4.

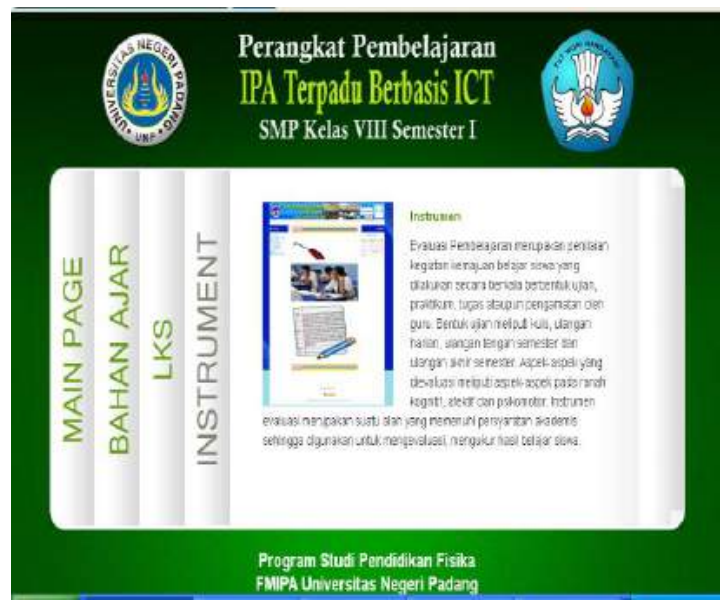

Gambar 4. Halaman Utama Evaluasi

Pada halaman utama evaluasi pembelajaran Sains terpadu berbasis ICT pengguna diberi gambaran tentang pengertian evaluasi, bentuk-bentuk eva luasi, aspek-aspek evaluasi, dan manfaat evaluasi pembelajaran. Pengguna dapat melakukan kegiatan evaluasi dengan mengklik evaluasi pada judul.

\section{KESIMPULAN}

Berdasarkan hasil pembahasan dapat dikemukakan kesimpulan sebagai berikut

1. Integrasi antara suatu bidang Sains dengan bidang Sains lainnya dapat dilakukan dengan salah satu dari model pembelajaran terpadu seperti terpisah, terhubung, terbagi, terintegrasi, dan sebagainya; integrasi nilai karakter kedalam bahan ajar dapat dilakukan melalui informasi, instruksi, dan analogi; dan integrasi keterampilan ICT kedalam bahan ajar melalui sistem navigasi.

2. Desain produk dari perangkat pembelajaran Sains terpadu berbasis ICT dengan mengintegrasikan nilai karakter terdiri dari bahan ajar, lembar kerja siswa, dan instrumen evaluasi berbasis ICT.

\section{DAFTAR PUSTAKA}

Anik Gufron, (2009). Integrasi Nilai-Nilai Karakter Bangsa Pada Kegiatan Pembelajaran. Universitas Negeri Yogyakarta.

Akhmad Sudrajat, (2010). Tentang Pendidikan Karakter. http://akhmad sudrajat. wordpress. com/2010/ 08/20/pendidikan-karakter-di-smp

Ari Gunawan, (2011). Pendidikan IPA Terpadu, Harus Bisa!. Kompasiana

Ceppy Riana, (2009). Teknologi Informasi dan Komunikasi (ICT) Dalam Pen didikan. http://klubgurusmi.files. wordpress com/2009/04/ makalahict-cepi.pdf

Das Salirawati, (2009). Pembelajaran Terpadu Untuk Mendukung Kreati vitas Siswa. Jurusan Pendidikan Kimia FMIPA UNY

Elsy Zuriyani, (2013). Literasi Sains dan Pendidikan. Kemenag Sumatera Selatan. 
Novi Resmini, (2012). Model-Model Pembelajaran Terpadu. Universitas Pendidikan Indonesia

Rudy Unesa, (2011). Pengertian dan Karakteristik Pembelajaran Terpadu. Universitas Negeri Surabaya

Suheri Shohei, (2011). Pengertian IPA Terpadu. http://suheriradovic. Blog spot. com/

Umi Rochayati, dkk, (2011). Peningkatan Kualitas Pembelajaran dan Memba ngun Karakter Kerja Pada Kuliah Praktik Teknik Digital Melalui Pembelajaran Berbasis Lesson Study. Fakultas Teknik Universitas Negeri Yogyakarta.

Yeni Hendriyani, (2010). Pengaruh Pembelajaran IPA Terpadu Terha dap Pengembangan Literasi Sains Siswa SMPN 3 Cimahi dan SMPN 1 Lembang. Pusat Pengembangan dan Pemberdayaan Pendidik dan Tenaga Kependidikan Ilmu Pengetahuan Alam Bandung. 